Atmos. Chem. Phys. Discuss., doi:10.5194/acp-2016-625, 2016

Manuscript under review for journal Atmos. Chem. Phys.

Published: 15 July 2016

(c) Author(s) 2016. CC-BY 3.0 License.

(c) (i)

\title{
Temperature-dependence of aerosol optical depth over the southeastern US
}

Tero Mielonen ${ }^{1}$, Anca Hienola ${ }^{2}$, Thomas Kühn ${ }^{1,3}$, Joonas Merikanto ${ }^{2}$, Antti Lipponen ${ }^{1}$, Tommi Bergman $^{1, *}$, Hannele Korhonen ${ }^{2}$, Pekka Kolmonen ${ }^{2}$, Larisa Sogacheva ${ }^{2}$, Darren Ghent ${ }^{4}$, Antti Arola ${ }^{1}$, 5 Gerrit de Leeuw ${ }^{2,5}$, and Harri Kokkola ${ }^{1}$

${ }^{1}$ Finnish Meteorological Institute, Kuopio, 70211, Finland,

${ }^{2}$ Finnish Meteorological Institute, Helsinki, 00560, Finland

${ }^{3}$ Department of Applied Physics, University of Eastern Finland, Kuopio, 70211, Finland

${ }^{4}$ Department of Physics \& Astronomy, University of Leicester, LE1 7RH, United Kingdom

$10{ }^{5}$ Department of Physics, University of Helsinki, 00560, Finland

*Now at: Royal Netherlands Meteorological Institute, De Bilt, 3731 GA, the Netherlands

Correspondence to: Tero Mielonen (tero.mielonen@fmi.fi)

Abstract. Previous studies have indicated that summer-time aerosol optical depths (AOD) over the southeastern US are

15 dependent on temperature but the reason for this dependence and its radiative effects have so far been unclear. To quantify these effects we utilized AOD and land surface temperature (LST) products from the Advanced Along-Track Scanning Radiometer (AATSR) with observations of tropospheric nitrogen dioxide $\left(\mathrm{NO}_{2}\right)$ column densities from the Ozone Monitoring Instrument (OMI). Furthermore, simulations of the global aerosol-climate model ECHAM-HAMMOZ have been used to identify the possible processes affecting aerosol loads and their dependence on temperature over the studied region.

20 Our results showed that the level of AOD in the southeastern US is mainly governed by anthropogenic emissions but the observed temperature dependent behaviour is most likely originating from non-anthropogenic emissions. Model simulations indicated that biogenic emissions of volatile organic compounds (BVOC) can explain the observed temperature dependence of AOD. According to the remote sensing data sets, the non-anthropogenic contribution increases AOD by approximately $0.009 \pm 0.018 \mathrm{~K}^{-1}$ while the modelled BVOC emissions increase AOD by $0.022 \pm 0.002 \mathrm{~K}^{-1}$. Consequently, the regional direct

25 radiative effect (DRE) of the non-anthropogenic AOD is $-0.43 \pm 0.88 \mathrm{~W} / \mathrm{m}^{2} / \mathrm{K}$ and $-0.17 \pm 0.35 \mathrm{~W} / \mathrm{m}^{2} / \mathrm{K}$ for clear- and all-sky conditions, respectively. The model estimate of the regional clear-sky DRE for biogenic aerosols is also in the same range: $0.86 \pm 0.06 \mathrm{~W} / \mathrm{m}^{2} / \mathrm{K}$. These DRE values indicate significantly larger cooling than the values reported for other forested regions. Furthermore, the model simulations showed that biogenic emissions increased the number of biogenic aerosols with radius larger than $100 \mathrm{~nm}$ (N100, proxy for cloud condensation nuclei) by $28 \%$ per one degree temperature increase. For the

30 total $\mathrm{N} 100$, the corresponding increase was $4 \%$ which implies that biogenic emissions could also have a small effect on indirect radiative forcing in this region. 
Atmos. Chem. Phys. Discuss., doi:10.5194/acp-2016-625, 2016

Atmospheric

Chemistry

Published: 15 July 2016

(c) Author(s) 2016. CC-BY 3.0 License.

and Physics

(c) $\underset{\mathrm{BY}}{\mathrm{B}}$

\section{Introduction}

Aerosol particles are an important regulator of the Earth's climate. They scatter and absorb incoming solar radiation (e.g. Charlson et al., 1992) and they can also act as initial formation sites for cloud droplets and thereby modify the properties and lifetime of clouds (Albrecht, 1989; Twomey, 1991; Stevens and Feingold, 2009). The magnitude of aerosol radiative effects

5 remains the single largest uncertainty in current estimates of anthropogenic radiative forcing (IPCC, 2013). One of the key quantities needed for accurate estimates of anthropogenic radiative forcing is an accurate estimate of the radiative effects from natural unperturbed aerosol - after all, it is the change from the natural background that is important when quantifying human influence on climate. In fact, recent studies have highlighted that uncertainties in natural aerosol emissions may bias our current estimates of aerosol forcing more than uncertainties associated with anthropogenic emissions (Carslaw et al.,

10 2013). Furthermore, our current understanding of future changes in natural aerosol radiative effects is very low.

The dominant source of natural aerosols over Earth's vast forested regions are biogenic volatile organic compounds (BVOC) which oxidate in the atmosphere forming semi- or non-volatile organic compounds. Consequently, these compounds can condense onto aerosol particles or participate in new particle formation to form secondary organic aerosol (SOA) and

15 significantly modify the particles' chemical and optical properties (Scott et al., 2014). In accordance with the expected positive temperature dependence of BVOC emissions (Duncan et al., 2009; Penuelas and Staudt, 2010; Stavrakou et al., 2015; Bauwens et al., 2016), several previous studies have shown that some aerosol properties, such as mass concentration and the ability to act as cloud condensation nuclei $(\mathrm{CCN})$, also correlate positively with temperature at many forested sites (e.g. Leaitch et al., 2011; Paasonen et al., 2013). Therefore, BVOC emissions could introduce a regionally relevant cooling

20 feedback in a warming climate (Scott et al., 2014). However, the evidence for temperature dependence of aerosol radiative effects due to increased BVOC emissions is not yet clear. Aerosol direct effects can be quantified via aerosol optical depth (AOD) from, e.g., satellites. Slowik et al. (2010) found correlated increases of in-situ observed SOA and regional satellite based AOD in Ontario, Canada, during periods of elevated temperature. Similarly, Goldstein et al. (2009) detected an exponential dependence between the temperature and AOD in the southeastern US, and hypothesized it to arise from enhanced natural BVOC emissions on warmer days. However, a subsequent study over the same area revealed that the previously observed correlation is predominantly associated with the occurrence of aerosols above the surface layer and the authors hypothized the source to be increased aqueous phase aerosol production (Ford and Heald, 2013). The links between temperature, BVOC emissions and AOD are further complicated over isoprene emitting forests, such as in the southeastern US, by the effect of isoprene oxidation on sulphate aerosol formation: major oxidation products of isoprene are peroxides,

30 which are generally attributed to the increased summertime formation of sulphate via aqueous phase reactions (Goldstein et al., 2009). 
Atmos. Chem. Phys. Discuss., doi:10.5194/acp-2016-625, 2016

The main objective of this study was to investigate the cause of the observed increase in AOD as a function of temperature over the southeastern US and to provide a quantitative estimate of the regional aerosol direct radiative effect and the resulting negative feedback in a warming climate. There are several aerosol sources that could explain the temperature dependence of AOD. For example, biogenic emissions, SOA formed in aqueous phase or biomass burning emissions could introduce temperature dependent components to the aerosol population. Due to the complicated nature of this phenomenon, the research was carried out using remote sensing observations accompanied by aerosol-climate model simulations. Together, they enabled a comprehensive analysis and estimation of the aerosol direct radiative effect.

\section{Methods}

As mentioned above, the study was conducted using a combination of remote sensing observations and climate modelling.

10 Key remote sensing data used in this study were the aerosol optical depth and land surface temperature products available from the ESA Aerosol_cci and ESA DUE GlobTemperature projects, together with ancillary data, such as tropospheric column density of nitrogen dioxide $\left(\mathrm{NO}_{2}\right)$ (Table 1). These observations were used to analyze the temperature dependence of AOD and the reasons behind the observed behaviour. For the modelling work we used the aerosol-chemistry climate model ECHAM-HAMMOZ, which describes the relevant atmospheric aerosol processes. The model enabled us to evaluate the

15 significance of different aerosol sources on the temperature dependency. The regional radiative effects of the temperature dependent AOD component were estimated from both observations and simulations. The study domain covered the southeastern US $\left(70-90^{\circ} \mathrm{W}\right.$ and $\left.30-37.5^{\circ} \mathrm{N}\right)$ for the years 2002-2011. A more detailed description of each data set and the model simulations are given below.

\subsection{Spaceborne observations}

\subsubsection{AATSR}

The core data sets for this study were provided by the Advanced Along Track Scanning Radiometer (AATSR), which flew on the ESA polar orbiting Environmental Satellite ENVISAT (2002-2012). It was a dual view imaging spectrometer with seven wavelength channels, four of them in the visible and near infrared $(0.555,0.659,0.865$, and $1.6 \mu \mathrm{m})$ and three in the shortwave infrared - thermal infrared $(3.7,11$, and $12 \mu \mathrm{m})$. AATSR had a swath width of $512 \mathrm{~km}$ and the spatial resolution

25 at nadir view was $1 \times 1 \mathrm{~km}^{2}$. The nadir view and the forward view at $55^{\circ}$ incident angle to the surface allowed for nearsimultaneous observation of the same area on the Earth's surface through two different atmospheric columns within $\sim 2$ minutes.

From the AATSR, AOD data available from the ESA Aerosol_cci project (Holzer-Popp et al., 2013; de Leeuw et al., 2015) 30 and LST data from ESA's DUE GlobTemperature project were used. More specifically, daily Level 3 AOD data with spatial resolution of $1 \times 1$ degrees from the full mission (2002-2012) were chosen because of the similarity in their spatial resolution 
Atmos. Chem. Phys. Discuss., doi:10.5194/acp-2016-625, 2016

to the resolution of the climate model which enabled a straightforward comparison between the observations and simulations. The Level 3 LST data with higher resolution $(0.01 \times 0.01$ degrees $)$ was regridded to $1 \times 1$-degree resolution to match the resolution of the AOD data.

5 Several algorithms have been developed for the retrieval of AOD from the AATSR observations. In this work we used the AOD retrievals done with the AATSR Dual-View (ADV) algorithm which is developed at the Finnish Meteorological Institute (Kolmonen et al., 2015). The algorithm uses both nadir and forward view measurements of top-of-the-atmosphere (TOA) reflectances to decouple atmospheric and surface contributions to the observed signal. The main product of the retrieval is AOD. Validation results have shown that the AOD values agree well with ground-based measurements ( $\mathrm{r}=0.85$, RMSE=0.09 over land). For a more detailed description of the algorithm see Kolmonen et al. (2015).

The LST algorithm uses pixel-by-pixel TOA radiometrically and geometrically calibrated brightness temperatures from the 11 and $12 \mu \mathrm{m}$ channels. The retrieval coefficients are dependent on the biome, fractional vegetation cover, precipitable water, satellite zenith view angle, and the time of day (day or night). Both the fractional vegetation cover and precipitable water are seasonally dependent whereas the biome is invariant. The Level 3 product exploited here has been cloud-cleared and re-gridded onto a regular equal-angle grid. For more information, see the AATSR LST Algorithm Theoretical Basis Document (Prata, 2002) and the Validation Report by Ghent (2012).

\subsubsection{OMI}

The Dutch-Finnish built Ozone Monitoring Instrument (OMI) is a nadir-viewing pushbroom UV/Visible instrument. It is onboard NASA's EOS-Aura satellite and part of the A-Train satellite constellation. OMI measures backscattered radiances in three wavelength intervals: 270-310 nm (UV-1), 310-365 nm (UV-2), and 350-500 nm (visible) at spectral resolutions of $0.42-0.63 \mathrm{~nm}$ (Levelt et al., 2006). It has a swath width of $2600 \mathrm{~km}$ and spatial resolution of $13 \times 48 \mathrm{~km}^{2}$ at nadir for the UV-1 channel, and $13 \times 24 \mathrm{~km}^{2}$ for the UV-2 and visible channels. OMI measures ozone, trace gases (e.g., $\mathrm{NO}_{2}, \mathrm{SO}_{2}$, $\mathrm{HCHO}, \mathrm{BrO}, \mathrm{CHOCHO}, \mathrm{OClO})$, aerosols and clouds.

25

In this work, the Level 3 tropospheric $\mathrm{NO}_{2}$ retrievals from the OMNO2d product were used (Bucsela et al., 2012). It consists of only good-quality pixel-level data that are averaged into a $0.25 \times 0.25$ degree global grid, and thus we re-gridded the data into $1 \times 1$ degree resolution to match the AATSR observations. The data contains $\mathrm{NO}_{2}$ column densities for all atmospheric conditions where cloud fraction is less than $30 \%$. For more information, see the documents provided by NASA GES DISC

30 (http://disc.gsfc.nasa.gov/Aura/OMI/documents). In this research, the tropospheric $\mathrm{NO}_{2}$ data were used as a proxy for anthropogenic emissions. 
Atmos. Chem. Phys. Discuss., doi:10.5194/acp-2016-625, 2016

Atmospheric

Chemistry

Published: 15 July 2016

(c) Author(s) 2016. CC-BY 3.0 License.

and Physics

Discussions

(c) (i)

\subsection{Aerosol-climate model}

In this study, the importance of different aerosol sources on the temperature dependence of AOD over the southeastern US was assessed using the development version of the global aerosol-climate model ECHAM-HAMMOZ (Stier et al., 2005; Zhang et al., 2012; Bergman et al., 2012; Laakso et al., 2016), version ECHAM6.1-HAM2.2-SALSA. The atmospheric

5 circulation model ECHAM solves the fundamental equations for the atmospheric flow, physics and tracer transport. The aerosol model HAM takes advantage of the Sectional Aerosol module for Large Scale Applications (SALSA) which was used to calculate aerosol microphysics (Kokkola et al., 2008; Bergman et al., 2012). SALSA describes the aerosol population consisting of sulphate $\left(\mathrm{SO}_{4}\right)$, sea salt, organic carbon (OC), black carbon (BC), and mineral dust, and uses 10 size sections to cover the size range from $3 \mathrm{~nm}$ to $10 \mu \mathrm{m}$. External mixing of aerosol particles was tracked with 10 additional sections.

10 Anthropogenic and biomass burning aerosol emissions were described with AeroCom-II Atmospheric Chemistry and Climate Model Intercomparison Project (ACCMIP) data (Riahi et al., 2007, 2011).

In our setup of ECHAM-HAMMOZ, organic mass is emitted both as primary organic matter (POM) and in form of volatile organic compounds (VOC). Anthropogenic VOCs simulated are xylene (XYL), toluene (TOL), and benzene (BENZ) and

15 they are entered into the model atmosphere based on emission inventories (Riahi et al., 2007, 2011). On the other hand, biogenic VOC emissions are computed online using the biogenic emissions model MEGAN (Model of Emissions of Gases and Aerosols from Nature, Guenther et al., 2006). In the setup presented here, the biogenic VOCs considered are isoprene (ISOP) and monoterpenes (MTP). Once emitted, all anthropogenic and biogenic VOCs are subject to gas-phase oxidation by hydroxyl $(\mathrm{OH})$, ozone $\left(\mathrm{O}_{3}\right)$ and nitrate $\left(\mathrm{NO}_{3}\right)$. The concentrations of $\mathrm{OH}, \mathrm{O}_{3}$ and $\mathrm{NO}_{3}$ are described with precomputed

20 climatological 3D fields from the MOZART model (Horowitz et al., 2003). The VOC oxidation products are grouped into two groups: the first contains organic compounds that form SOA by gas-to-particle partitioning. The oxidation products are categorized according to their volatility, i.e. equilibrium concentrations, using the volatility basis set (VBS) approach (Donahue et al., 2011). The gas-to-particle partitioning scheme of these products is described by Kokkola et al. (2014). The second group contains the organic compounds that form SOA through aqueous phase chemistry, i.e. in our set-up isoprene epoxydiols (IEPOX) and glyoxals (GLYX). For more details of these schemes, see Kühn et al. (in preparation). These processes were included in the model to test the hypothesis for the temperature dependence of AOD given by Goldstein et al. (2009) and Ford and Heald (2013).

For biomass burning emissions, the Global Fire Emissions Database (GFEDv2; Randerson et al., 2007) was used. The

30 activation of aerosol particles into cloud droplets was calculated with the semi-empirical parameterization of Lin and Leaitch (1997). The simulations were done using T63 horizontal resolution (roughly $1.9 \times 1.9^{\circ}$ ) and 31 pressure levels that reached up to $10 \mathrm{hPa}$. Model's large scale circulation in our simulations was nudged towards ECMWF reanalysis data (ERA-Interim; 
Atmos. Chem. Phys. Discuss., doi:10.5194/acp-2016-625, 2016

Manuscript under review for journal Atmos. Chem. Phys.

Published: 15 July 2016

(c) Author(s) 2016. CC-BY 3.0 License.

Berrisford et al., 2011) to ensure compatibility between the model and the observed atmospheric conditions. The simulation period was 2002-2010 with a three month spin-up.

To estimate how different aerosol sources affect the aerosol load over the southeastern US $\left(70-90^{\circ} \mathrm{W}\right.$ and $\left.30-37.5^{\circ} \mathrm{N}\right)$, four

simulations were performed:

1) CONTROL (all the schemes described above are in use, daily averages);

2) noBIOSOA (same as CONTROL but without biogenic SOA formation, 3-hourly averages);

3) noBB (same as CONTROL but without biomass burning emissions, 3-hourly averages);

4) noAQSOA (same as CONTROL but without SOA formed in aqueous phase, 3-hourly averages).

10

This set of simulations was chosen because they cover the most important aerosol sources that might introduce a temperature dependent component into AOD at the studied region (e.g. Goldstein et al., 2009; Ford and Heald, 2013). The importance of each aerosol source (biogenic SOA formation, biomass burning, and SOA formed in aqueous phase) was estimated by comparing the simulation without that source to the CONTROL run.

\section{$15 \quad 2.3$ Statistical methods}

The selected satellite and model data sets do not contain uncertainty estimates that can be utilized in this study. Therefore, we computed the estimates of uncertainty caused by averaging using bootstrapping (Efron and Tibshirani, 1993). Bootstrapping is a commonly used statistical method that may be used to assign measures of uncertainty to sample estimates. In practice, we constructed 1000 data point sets by randomly sampling from the original data points and calculated averages

20 for these new sets. Furthermore, the standard deviations of the set averages were computed and used as the measure of uncertainty in the analysis.

In order to find linear relationships between the different variables analysed in this study, we fitted linear models to the data sets using Bayesian inference. A Markov chain Monte Carlo method was employed to produce a conditional mean estimate for the linear model parameters (Gelman et al., 2014). By carrying out the linear model parameter estimation using this method we were able to take into account the uncertainties in both the dependent and independent variables and thus producing more realistic estimates for the linear model parameters than by using the ordinary least squares fitting. Furthermore, the used approach produced credibility intervals for the estimated parameters which were used as uncertainty ranges for the derived estimates. The Bayesian inference was carried out using the Stan software (Carpenter et al., 2016)

30 following the example for "Regression with Measurement Error" given in Stan Modeling Language: User's Guide and Reference Manual, version 2.9.0. (Stan Development Team, 2015). 
Atmos. Chem. Phys. Discuss., doi:10.5194/acp-2016-625, 2016

Manuscript under review for journal Atmos. Chem. Phys.

\section{Results}

\subsection{Spaceborne observations}

As the first step, the anomalies of the regional mean LST and AOD as retrieved from the AATSR observations were calculated for the summers (JJA) of the years 2003-2011 (full summers available for each year). As Figure 1 shows, there is no clear correlation between LST and AOD anomalies for the studied time period. This lack of correlation seems to be in contradiction with the results of Goldstein et al. (2009) who presented a linear correlation between AOD (retrieved from Multi-angle Imaging SpectroRadiometer (MISR) data) and temperature (from Goddard Institute for Space Studies (GISS)) for the years 2000-2005. However, a more detailed inspection of Figure 1 reveals that the data points can be divided into two subgroups based on the sign of the AOD anomaly and within these groups AOD increases as temperature increases.

10 Moreover, both groups contain data from consecutive years: positive AOD anomalies occur in the years 2003-2007 and negative anomalies in the years 2008-2011. This implies that between the years 2007 and 2008 there has been a change in the emission of aerosols or their precursors.

To study the impact of anthropogenic emissions on AOD in this region, retrievals of tropospheric $\mathrm{NO}_{2}$ column densities

15 available from OMI (only available from 2005 onwards) were used. $\mathrm{NO}_{2}$ can be considered a proxy for anthropogenic influence since the main sources of nitrogen oxides in this region are combustion from transportation and electric generating units (Hidy et al., 2014). When summertime anomalies of tropospheric $\mathrm{NO}_{2}$ column densities are compared with corresponding AOD anomalies, their correlation is clear, as can be seen from Figure 2a. The years 2005-2007 exhibit positive tropospheric NO2 and AOD anomalies whereas the years 2008-2011 have negative anomalies. Figure $2 \mathrm{~b}$ shows the

20 temporal changes in the annual and summertime average concentrations of tropospheric $\mathrm{NO}_{2}$. Clearly, the concentrations have decreased through the years and this decrease is in line with the reductions of anthropogenic emissions in the studied region (e.g. Krotkov et al. (2016); Attwood et al. (2014); Hidy et al. (2014); Blanchard et al. (2013); Hand et al. (2012)). The emissions have decreased for several years due to emission control measures but the economic crisis in 2007-2009 augmented the reduction rate of the emissions further (Russell et al. (2012)). Consequently, AOD and tropospheric $\mathrm{NO}_{2}$ values in Figure 2a fall into two distinct groups, separation happening between the years 2007 and 2008.

As can be seen from Figure 2a, there is almost a linear relationship between anthropogenic emissions and AOD in this region on a seasonal level. A linear fit for the absolute summer averages of tropospheric $\mathrm{NO}_{2}$ and AOD (similar dependence as for the anomalies in Figure 2a) implies that an increase in the column density of tropospheric $\mathrm{NO}_{2}$ by $2 \times 10^{14}$ molecules $/ \mathrm{cm}^{2}$ 30 ( $10 \%$ of the average column density) corresponds to an increase of 0.07 ( $20 \%$ of the average) in AOD. However, tropospheric $\mathrm{NO}_{2}$ anomalies do not exhibit dependence on temperature anomalies (shown with colour in Figure 2a) thus there must be some other source of aerosols or a mechanism which is responsible for the temperature dependence of AOD visible in Figure 1. 
Atmos. Chem. Phys. Discuss., doi:10.5194/acp-2016-625, 2016

Manuscript under review for journal Atmos. Chem. Phys.

The results discussed above indicate that the total AOD level is controlled by anthropogenic emissions which are independent of temperature but when the two groups in Figure 1 are studied separately, it seems that both of them have a positive temperature dependent behaviour. This is evident when linear fits to these groups are made separately, as shown in

5 Figure 1. The y-intercept of the fitted linear equations are very different due to the changes in the level of anthropogenic pollution but the slopes are quite similar; 0.012 $\pm 0.010 \mathrm{~K}^{-1}$ for the years 2003-2007 and 0.019 $\pm 0.013 \mathrm{~K}^{-1}$ for $2008-2011$ (the uncertainty ranges are the credibility intervals with $80 \%$ probability from the Bayesian inference). We calculated a linear fit also from the MISR AOD and GISS temperature anomalies presented by Goldstein et al. (2009) for the years 2000-2005. The resulting slope of $0.013 \mathrm{~K}^{-1}\left(A O D_{a n o}=0.013 L S T_{\text {ano }}-0.006\right.$, based on an ordinary least squares fit corrected with the

10 correlation coefficient (Frost and Thompson, 2000)) was almost identical to the slope for the years 2003-2007 in our analysis. The detection of the phenomenon with independent observations is a strong indicator that it is most likely real and not a fortuitous feature in the measurement data. The positive temperature trend is found also for the monthly mean anomalies (linear fits of $\left(A O D_{a n o}=0.024 L S T_{a n o}+0.036\right.$ and $A O D_{\text {ano }}=0.008 L S T_{\text {ano }}-0.050$, for the years $2003-2007$ and 2008-2011, respectively; see Supplement for details) similar to the summer mean values shown here. These results

15 imply that over the studied period there is a temperature-dependent component in the summertime AODs over the southeastern US but its impact on the total AOD is considerably smaller than that due to reductions in anthropogenic emissions.

To investigate whether non-anthropogenic emissions could cause the observed temperature dependence of AOD, we first

20 removed the estimated anthropogenic contribution from the total AOD using observations of tropospheric $\mathrm{NO}_{2}$. Veefkind et al. (2011) had shown that over the eastern US the same sources that emit $\mathrm{NO}_{\mathrm{x}}$ also drive the AOD values. Consequently, the anthropogenic contribution was estimated by calculating a linear fit between the summertime AOD and tropospheric $\mathrm{NO}_{2}$ columns $\left(A O D=3.37 e^{-16} \mathrm{NO}_{2, \text { trop }}-0.414\right.$; monthly anomalies produced a comparable relationship, see Supplement for details).Using this relationship the anthropogenic AOD was estimated from the observed tropospheric $\mathrm{NO}_{2}$ values and the non-anthropogenic AOD was estimated by subtracting the anthropogenic AOD from the total AOD. Then we calculated the summertime anomalies for the anthropogenic and non-anthropogenic AODs. The anthropogenic AOD anomalies did not correlate with LST anomalies, which was to be expected because tropospheric $\mathrm{NO}_{2}$ columns did not correlate with LST, as discussed earlier. The non-anthropogenic AOD anomalies, on the other hand, had a moderate positive correlation $(\mathrm{R}=0.44$, p-value $=0.33)$ with LST as can be seen from Figure 3. We also made a linear fit to the data $\left(A O D_{N A, a n o}=0.009 L S T_{a n o}-\right.$ 30 0.0008; monthly anomalies produced a comparable relationship, see Supplement for details) to estimate how much the nonanthropogenic AOD increases with temperature increase. The slope of $0.009 \pm 0.018 \mathrm{~K}^{-1}$ is slightly smaller than the slopes in Figure 1 but still in the same range. The uncertainty range of the slope is large but most likely it is positive and below 0.027 $\mathrm{K}^{-1}$. This information is useful for the estimation of the radiative effect of the temperature dependent AOD component. 
Atmos. Chem. Phys. Discuss., doi:10.5194/acp-2016-625, 2016

Atmospheric

Manuscript under review for journal Atmos. Chem. Phys.

Chemistry

Published: 15 July 2016

(c) Author(s) 2016. CC-BY 3.0 License.

$\frac{\text { and Physics }}{\text { Discussions }}$

(c) (i)

The results presented above imply that the temperature dependence of AOD over the southeastern US is caused by other than anthropogenic aerosol sources. One candidate for the dependence is emissions from biomass burning. Therefore, the Fire radiative power (FRP, Kaufman Giglio et al., 2003) data from the Moderate Resolution Imaging Spectroradiometer (MODIS) which describes the intensity of fires was used as a proxy for biomass burning emissions. The FRP data showed

5 similar summer averages from year to year and the summertime FRP anomalies did not show any correlation with corresponding AOD or LST anomalies (see Supplement for details). Consequently, the most likely candidate for the dependence is temperature dependent biogenic emissions. To investigate if changes in vegetation state were linked with the non-anthropogenic AOD anomalies, several remote sensing data sets regarding vegetation state were analyzed (see Supplement for details): Leaf Area Index (LAI, Knyazikhin et al., 1999) and Fraction of Absorbed Photosynthetically Active

10 Radiation (FPAR, Knyazikhin et al., 1999) products from MODIS, soil moisture data from ESA Soil moisture_cci (Liu et al., 2011; Liu et al., 2012; Wagner et al., 2012) and the scientific vegetation fluorescence (SCI_FSC, Joiner et al., 2012) product from the SCanning Imaging Absorption spectroMeter for Atmospheric CHartographY (SCIAMACHY). Only the fluorescence product had a clear relationship with the non-anthropogenic AOD anomalies: vegetation fluorescence anomalies were inversely correlated with the anthropogenic AOD anomalies $(\mathrm{R}=-0.78, \mathrm{p}$-value $=0.04)$. This relationship

15 implies that at higher temperatures the plants emit more VOCs which is associated with lower fluorescence (e.g. Loreto and Schnitzler, 2010; Flexas et al., 2011; Pollastri et al., 2013). Thus, the temperature dependent non-anthropogenic AOD component is likely originating from a biogenic source. As only one of the satellite products indicated that the temperature dependency of AOD could be caused by biogenic emissions, we were not able to confirm the reason for the temperature dependence of AOD relying solely on remote sensing data. Therefore, we continued the analysis using an aerosol-climate model.

\subsection{Model simulations}

The first step in the model analysis was to confirm that the ECHAM-HAMMOZ model was able to reproduce the behaviour of the remote sensing observations presented in section 3.1 and to ensure that the model could be used to identify the processes that are responsible for the temperature dependent behaviour of AOD. The monthly AOD and LST averages from the control simulation (CONTROL) produced good correspondence with the values from the AATSR retrievals for the years 2002-2010 (see Supplement for details) even though the satellite data were limited to daytime values only whereas the model averages included also night-time values. Direct comparison between daytime values was not possible because daily averages were the best temporal resolution available from this simulation. The correlation coefficient for the AOD values was 0.77 ( $\mathrm{p}$-value $=3.1 \mathrm{e}^{-21}$ ), the model overestimating the lowest AOD values but underestimating the largest ones. For the

30 LST values, the correlation coefficient was $0.94\left(\mathrm{p}\right.$-value $\left.=2.6 \mathrm{e}^{-48}\right)$, the highest temperatures being underestimated in the model due to the inclusion of night-time temperatures in the model averaging. Thus, the modelled values correspond well with the observations, which gives confidence that the model results can be used to illuminate the mechanism behind the observed phenomena. 
Atmos. Chem. Phys. Discuss., doi:10.5194/acp-2016-625, 2016

Manuscript under review for journal Atmos. Chem. Phys.

As the next step, the summertime anomalies for AOD and LST from the CONTROL run were calculated and compared with the corresponding anomalies from the observations. These results are shown in Figure 4. As one can see, the modelled anomalies have a similar behaviour as the observations presented in Figure 1: there is no clear temperature dependence in

5 AOD when the whole time period is studied but separation of the summers based on the atmospheric $\mathrm{SO}_{4}$ burdens (used as a proxy for anthropogenic effect, since $\mathrm{NO}_{2}$ is not included in the model) reveals two groups that have similar AODtemperature dependencies. However, there are also clear differences: the modelled AOD variability is only half of the observed variability, the AOD difference between the two groups is only half of the observed difference, and the increases in AOD per degree temperature increase $\left(0.007 \pm 0.007 \mathrm{~K}^{-1}\right.$ and $0.006 \pm 0.004 \mathrm{~K}^{-1}$ for the two groups; monthly anomalies

10 produced a comparable relationship, see Supplement for details) are about half or one third of the values derived from the measurements. Furthermore, the group with the negative AOD anomalies does not contain only consecutive years, because the model was not able to reproduce perfectly the effect of changing anthropogenic emissions on AOD. Moreover, the smaller changes in the AOD are most likely caused by simplifications in the way emissions are handled by the model. For example, the anthropogenic emissions do not have a daily or a yearly cycle which means that for a single year every day has

15 the same constant emission fluxes equal to the annual averages. Consequently, this reduces the dynamical range of the emissions and their effect on AOD. However, biomass burning, sea salt, desert dust and biogenic emissions are not constant.

To identify the processes responsible for the modelled temperature dependence of AOD, we carried out sensitivity simulations in which individual processes were turned off one by one. Monthly mean AOD values (summers 2002-2010)

20 from these simulations were subtracted from the corresponding values from the CONTROL run to identify the contribution of different processes to the AOD temperature dependence. Figure 5 presents this comparison. The simulations without aqueous phase SOA (noAQSOA) and without biomass burning emissions (noBB) produced quite similar AOD values as the CONTROL run, thus these aerosol sources did not have a notable impact on the aerosol population and on the temperature dependence of AOD. The only substantial change to the AOD values $\left(0.022 \pm 0.002 \mathrm{~K}^{-1}\right)$ comes from the inclusion of

25 biogenic SOA and it depends strongly on temperature as the figure shows. The slope of this change is in the same range as the slopes estimated from the remote sensing observations for the temperature dependence of summertime AOD over the southeastern US (Figures 1 and 3).

To investigate the differences between the simulations in more detail, the daily AOD cycles from a warm and a cold summer 30 (JJA) were compared. Figure 6 describes the average daily cycles of AOD for the summers 2008 and 2009 from the sensitivity simulations (CONTROL simulation is not included because it had outputs with daily resolution only). The averages were calculated from 90 days. In the model simulations, summer 2008 was warmer than average and 2009 colder than average and this is reflected in the AODs of the simulations which include the biogenic emissions calculated with MEGAN (noBB and noAQSOA). In these simulations, warmer summer produces larger AODs because the biogenic 
Atmos. Chem. Phys. Discuss., doi:10.5194/acp-2016-625, 2016

Manuscript under review for journal Atmos. Chem. Phys.

Chemistry

Published: 15 July 2016

(c) Author(s) 2016. CC-BY 3.0 License.

emissions increase with increasing temperature. This is reflected in the noBIOSOA simulation, which does not show a clear difference between the summers and the overall AODs are lower than in the other simulations. More importantly, this figure implies that there is a delay in the effect of the biogenic emissions on AOD. In the model, biogenic emissions peak at midday but the AODs begin to increase 6-12 hours later as the organic gases condense on particles and increase their size. This can

5 be seen from Figure 6 by comparing the noAQSOA summers: the largest differences in AOD occur during the night. Other studies have shown that oxidation of organic emissions into SOA takes at least several hours, which supports our findings (e.g.Camredon et al., 2007).

In summary, the model results are in line with the satellite observations when the biogenic emissions are included in the

10 simulations and from the studied processes only the biogenic VOC emissions could explain the temperature dependence of summertime AOD. This implies that the temperature dependence of the non-anthropogenic AOD derived from the observations is most likely explained with SOA formed from biogenic VOC emissions.

\subsection{Radiative impacts}

In order to estimate the climate effect of the non-anthropogenic (or biogenic) emissions in the southeastern US, the regional

15 direct radiative effects (DRE) were calculated from the observations and the simulations. For the measurement based estimate, the linear fit between the non-anthropogenic AOD and temperature anomalies from the Figure 3 was used: $A O D_{N A, \text { ano }}=0.009 L S T_{\text {ano }}-0.0008$. The slope of $0.009 \pm 0.018 \mathrm{~K}^{-1}$ represents our best estimate with $80 \%$ probability. Using this AOD change per temperature degree in the following equation we estimated the regional DRE of the nonanthropogenic AOD (e.g. Haywood and Shine, 1995):

$D R E=S_{r a d} \phi A O D\left(1-C_{c}\right) T_{a t m}^{2}\left(1-R_{s}\right)^{2}\left(2 R_{s} \frac{1-\varpi}{\left(1-R_{s}\right)^{2}}-\beta \varpi\right)$

where $S_{\text {rad }}$ is the incident solar radiation $\left(461 \mathrm{~W} / \mathrm{m}^{2}\right)$ at the top of the atmosphere, $\phi$ is the mean daytime value of the secant of the solar zenith angle (1.33), $C_{c}$ fractional cloud amount ( 0.0 for clear-sky and 0.6 for all-sky), $T_{a t m}$ aerosol free atmospheric transmission (0.76), $R_{s}$ surface reflectance (0.15), $\omega$ single scattering albedo (0.972) and $\beta$ up-scatter fraction (0.21). All the values for the equation, except for $S_{\text {rad }}$ and $\phi$, were taken from Goldstein et al. (2009). The region and season averaged $S_{\text {rad }}$ and $\phi$ were calculated with the help of the tools in the LibRadtran package (Emde et al., 2016). Consequently, the measurement based DRE estimates are $-0.43 \pm 0.88 \mathrm{~W} / \mathrm{m}^{2} / \mathrm{K}$ and $-0.17 \pm 0.35 \mathrm{~W} / \mathrm{m}^{2} / \mathrm{K}$ for clear- and all-sky conditions, respectively.

As a next step, we estimated the summertime clear-sky DRE of biogenic aerosols from the model simulations by calculating

30 the difference between the net clear sky top-of-atmosphere solar radiation from the CONTROL and the noBIOSOA simulations as a function of temperature anomalies. A linear fit to the data set produced the following function: $D R E=$ 
Atmos. Chem. Phys. Discuss., doi:10.5194/acp-2016-625, 2016

Manuscript under review for journal Atmos. Chem. Phys.

$-0.86 L S T_{\text {ano }}-1.57$. Thus, a one Kelvin increase in temperature corresponds to a biogenic DRE of $-0.86 \pm 0.06 \mathrm{~W} / \mathrm{m}^{2}$. The simulation based clear-sky DRE estimate is twice as large as the measurement based. This was to be expected because the modelled increase in AOD due to biogenic emissions was twice as large as the observed increase. However, a factor of two difference in the estimates can be considered as a good agreement due to the uncertainties in both methods.

When compared with the DRE and cloud albedo effect estimates presented by Paasonen et al. (2013) for several locations, our DRE estimates are more negative. For the growth season $\left(\mathrm{T}>5{ }^{\circ} \mathrm{C}\right)$ Paasonen et al. reported DRE and cloud albedo effect (first indirect effect) averages of $-0.03(-0.060-0.006) \mathrm{W} / \mathrm{m}^{2} / \mathrm{K}$ and $-0.19(-0.76-0.06) \mathrm{W} / \mathrm{m}^{2} / \mathrm{K}$, respectively. Thus, our DRE estimates are in the same range as their estimates for the cloud albedo effect. Furthermore, our DRE estimates

10 imply substantially stronger cooling than the estimates by Lihavainen et al. (2015) for a site in the boreal region ($0.097 \pm 0.066 \mathrm{~W} / \mathrm{m}^{2} / \mathrm{K}$ and $-0.063 \pm 0.040 \mathrm{~W} / \mathrm{m}^{2} / \mathrm{K}$ ). These comparisons indicate that the biogenic SOA contribution to DRE in the southeastern US is more pronounced than in the other studied regions.

Based on a similar equation as Eq. 1 and AOD observations done with MISR Goldstein et al. (2009) had estimated that the 15 all-sky DRE of the summertime aerosols in this region would be $-3.9 \mathrm{~W} / \mathrm{m}^{2}$ (although they called it erroneously clear-sky). They estimated the radiative effect as a difference between summertime and wintertime AODs (resulting in AOD difference of 0.18$)$. For a clear-sky case $\left(C_{c}=0\right)$ their DRE estimate would be $-9.75 \mathrm{~W} / \mathrm{m}^{2}$. In order to get comparable estimates, we also calculated the mean difference between summer and winter (DJF) AODs. Based on the AATSR data, the seasonal AOD difference was 0.22. Furthermore, we calculated the mean difference between summer and winter LSTs and used that 20 temperature change in the linear fit between the non-anthropogenic AOD and temperature anomalies to get the corresponding change in the non-anthropogenic AOD. These calculations resulted in a temperature difference of $19 \mathrm{~K}$ and a non-anthropogenic AOD change of $0.17 \pm 0.33$. This change is almost as large as the total seasonal AOD difference which implies that the difference between the winter- and summertime AODs could mainly be explained with non-anthropogenic (or biogenic) emissions as Goldstein et al. discussed. Using the AOD change in the Eq. 1 produced DRE estimates of -

$258.16 \pm 16.82 \mathrm{~W} / \mathrm{m}^{2} / \mathrm{K}$ and $-3.26 \pm 6.73 \mathrm{~W} / \mathrm{m}^{2} / \mathrm{K}$ for clear- and all-sky conditions, respectively. Moreover, we also estimated the clear-sky DRE of biogenic aerosols from the model simulations by calculating the difference between the net clear sky topof-atmosphere solar radiation from the CONTROL and the noBIOSOA runs for the summer months. This leads to an average clear-sky DRE of $-1.52 \pm 0.71 \mathrm{~W} / \mathrm{m}^{2}$ for the summertime biogenic aerosols in the southeastern US. This is significantly smaller than the measurement based estimates which implies that they are most likely overestimating the

30 biogenic effect.

As the DRE estimates showed, biogenic SOA has a significant direct radiative effect on a regional scale. However, biogenic SOA also increases the size and number of cloud condensation nuclei $(\mathrm{CCN})$ which can affect the indirect radiative forcing. Our model results showed that the number concentration of particles with dry diameters larger than $100 \mathrm{~nm}$ (N100; a proxy 
Atmos. Chem. Phys. Discuss., doi:10.5194/acp-2016-625, 2016

for $\mathrm{CCN}$ ) is significantly affected by biogenic SOA; in the summertime $45 \%$ of the N100 particles over the sourtheastern US are produced by this source. This result is in good agreement with the corresponding estimate of $50 \%$ given for Europe by Paasonen et al. (2013). Based on the difference between the summertime monthly mean N100 values of the CONTROL and the noBIOSOA simulations we estimated that the biogenic N100 (particles containing biogenic SOA) increases by $28 \%$

5 for one Kelvin increase in temperature. This is a significant change; however the total N100 value increases only by $4 \%$ per Kelvin due to biogenic emissions. This indicates that biogenic SOA might also have a small effect on indirect radiative forcing in the studied region.

\section{Summary}

By using satellite remote sensing observations from AATSR and OMI and aerosol-climate model ECHAM-HAMMOZ in 10 concert we made a detailed analysis of the reasons behind the observed temperature dependence of AOD over the southeastern US. We found that for the period 2003-2011, the relationship between LST and AOD is masked by a significant reduction in anthropogenic emissions. Anthropogenic emissions are the main driver of AOD levels in this region. For example, a decrease of $2 \times 10^{14}$ molecules $/ \mathrm{cm}^{2}$ in the tropospheric $\mathrm{NO}_{2}$ concentration ( $10 \%$ of the average concentration) corresponds to a decrease of 0.06 ( $20 \%$ of average $)$ in AOD. When the observations were separated into two groups based

15 on the amount of anthropogenic pollution (2003-2007 and 2008-2011), the dependence of AOD on LST was clear in both of them. The AOD-LST dependence was similar in both the polluted and the less polluted cases: the AOD increases by 0.01 $0.02 \mathrm{~K}^{-1}$ during the summers.

The role of anthropogenic emissions in the temperature dependence of AOD was investigated by separating the AATSR

20 AOD anomalies into anthropogenic and non-anthropogenic components using tropospheric $\mathrm{NO}_{2}$ observations from OMI. This analysis showed that anthropogenic AOD is not temperature dependent but the non-anthropogenic AOD is and the temperature dependence of the non-anthropogenic AOD $\left(0.009 \pm 0.018 \mathrm{~K}^{-1}\right)$ is in the same range as observed for the total AOD. Even though observations of vegetation fluorescence indicated that the non-anthropogenic AOD and the temperature dependence of the AOD could have a biogenic source, we were not able confirm this using remote sensing observations alone. Therefore, the analysis was complemented with the ECHAM-HAMMOZ climate model.

The modelled AOD and surface temperature values for the summer months were in line with the satellite observations. Thus, the simulations were used to identify the most likely process behind the temperature dependence of AOD. The simulation results from the CONTROL run (including all the relevant processes) agreed qualitatively with the measurements: they did

30 not show a clear temperature dependence in AOD when the whole time period was studied but separation of the years based on SO4 burdens (a proxy for the anthropogenic effect) revealed two groups that have similar AOD-temperature dependencies. However, the modelled AOD variability was only half of the measured variability, the total AOD difference 
Atmos. Chem. Phys. Discuss., doi:10.5194/acp-2016-625, 2016

between the two groups was half of the measured difference and the increase in AOD per Kelvin $\left(0.007 \pm 0.007 \mathrm{~K}^{-1}\right.$ and $0.006 \pm 0.004 \mathrm{~K}^{-1}$ for the two groups) were about half or one third of the values derived from the measurements. The smaller changes in the modelled AODs were most likely caused by differences between the model emissions and the actual emissions. The modelled SOA formation in the aqueous phase did not have a significant effect on aerosol burdens and it had

5 no dependence on temperature. Biomass burning emissions had some impact on aerosol burdens but they were not temperature dependent. Only the inclusion of biogenic emissions (BVOCs) produced clear temperature dependence in AOD. The model also showed that the AOD values were affected by the VOC emissions with a time delay of $\sim 6-12$ hours and that the increase in AOD due to VOC emissions was $0.022 \pm 0.002$ per Kelvin which is in the same range as the observed change in AOD due to non-anthropogenic sources. This implies that BVOC emissions in this region are significant enough to explain the observed temperature dependence of AOD.

Based on the remote sensing measurements we estimated that over the southeastern US the clear- and all-sky DREs of nonanthropogenic (biogenic SOA) component are $-0.43 \pm 0.88 \mathrm{~W} / \mathrm{m}^{2} / \mathrm{K}$ and $-0.17 \pm 0.35 \mathrm{~W} / \mathrm{m}^{2} / \mathrm{K}$, respectively. The corresponding model estimate for the clear-sky DRE is $-0.86 \pm 0.06 \mathrm{~W} / \mathrm{m} 2 / \mathrm{K}$, thus both estimates are in reasonable agreement and

15 significantly larger than the values reported for other forested regions (e.g. Paasonen et al., 2013). Furthermore, the model simulations showed an effect of biogenic VOCs on N100 (a proxy for CCN) in this region. An increase in biogenic emissions due to a one Kelvin increase in temperature increased biogenic N100 (particles containing biogenic SOA) by $28 \%$ and the total N100 by $4 \%$. This indicates that biogenic SOA might also have a small effect on indirect radiative forcing over the southeastern US.

\section{Data availability}

The satellite data sets used in the analysis are publicly available from the depositories mentioned in Table 1. All global model results and the processed remote sensing observations are available from the first author upon request. Please contact via e-mail using tero.mielonen@fmi.fi.

\section{Competing interests}

25 The authors declare that they have no conflict of interests.

\section{Acknowledgements}

This work was funded by the ESA Living Planet Fellowship (ESA contract No. 4000112802/14/I-SBo), the Academy of Finland Centre of Excellence in Atmospheric Science (272041) and Academy Research Fellowship (250348, 256208), and 
Atmos. Chem. Phys. Discuss., doi:10.5194/acp-2016-625, 2016

Atmospheric

Manuscript under review for journal Atmos. Chem. Phys.

Chemistry

Published: 15 July 2016

(c) Author(s) 2016. CC-BY 3.0 License.

$\frac{\text { and Physics }}{\text { Discussions }}$

(c) $\underset{\mathrm{BY}}{(i)}$

the Nordic Center of Excellence eSTICC (sScience Tool for Investigating Climate Change in northern high latitudes) funded by Nordforsk (grant 57001). We acknowledge the OMI mission scientists and associated NASA personnel for the production of the data used in this research, the ESA Climate Change Initiative and in particular the Aerosol_cci project. The ATSR GlobTemperature Level-2/Level-3 v1.0 LST data were made available through the GlobTemperature Data Portal and were generated through the ESA DUE GlobTemperature Project with the support of NCEO. The ECHAM-HAMMOZ model is developed by a consortium composed of ETH Zurich, Max Planck Institut für Meteorologie, Forschungszentrum Jülich, University of Oxford, the Finnish Meteorological Institute, and the Leibniz Institute for Tropospheric Research and managed by the Center for Climate Systems Modeling (C2SM) at ETH Zurich. The authors thank Dr. Joanna Joiner for the help in the analysis of the vegetation fluorescence data from SCIAMACHY.

10

Albrecht, B. A.: Aerosols, Cloud Microphysics, and Fractional Cloudiness. Science 245 (4923): 1227-30, 1989.

Attwood, A. R., Washenfelder, R. A., Brock, C. A., Hu, W.,Baumann, K., Campuzano-Jost, P., Day, D. A., Edgerton, E. S., Murphy, D. M., Palm, B. B., McComiskey, A., Wagner, N. L., de Sá, S. S., Ortega, A., Martin, S. T., Jimenez, J. L., Brown, 15 S. S.: Trends in sulfate and organic aerosol mass in the Southeast U.S.: Impact on aerosol optical depth and radiative forcing, Geophys. Res. Lett., 41, 7701-7709, doi:10.1002/2014GL061669, 2014.

Bauwens, M., Stavrakou, T., Müller, J.-F., De Smedt, I., Van Roozendael, M., van der Werf, G. R., Wiedinmyer, C., Kaiser, J. W., Sindelarova, K., and Guenther, A.: Nine years of global hydrocarbon emissions based on source inversion of OMI formaldehyde observations, Atmos. Chem. Phys. Discuss., doi:10.5194/acp-2016-221, in review, 2016.

Bergman T., Kerminen V.-M., Korhonen H., Lehtinen K. E. J., Makkonen R., Arola A., Mielonen T., Romakkaniemi S., Kulmala M., Kokkola H.: Evaluation of the sectional aerosol microphysics module SALSA implementation in ECHAM5HAM aerosol-climate model. Geosci. Model. Dev., 5, 845 - 868; doi:10.5194/gmd-5-845-2012, 2012.

25

Berrisford, P., Dee, D. P., Poli, P., Brugge, R., Fielding, K., Fuentes, M., Kållberg, P. W., Kobayashi, S., Uppala, S., and Simmons, A.: The ERA-Interim archive Version 2.0. ERA Report Series, European Centre for Medium Range Weather Forecasts, 2011.

30 Blanchard ,C. L., Hidy , G. M., Tanenbaum , S., Edgerton, E. S., Hartsell, B. E.: The Southeastern Aerosol Research and Characterization (SEARCH) study: Temporal trends in gas and PM concentrations and composition, 1999-2010, Journal of the Air \& Waste Management Association, 63:3, 247-259, DOI: 10.1080/10962247.2012.748523, 2013. 
Atmos. Chem. Phys. Discuss., doi:10.5194/acp-2016-625, 2016

Manuscript under review for journal Atmos. Chem. Phys.

Published: 15 July 2016

(c) Author(s) 2016. CC-BY 3.0 License.

(c) (i)
Atmospheric

Chemistry

and Physics

Discussions

Bucsela, E. J., Krotkov, N. A., Celarier, E. A., Lamsal, L. N., Swartz, W. H., Bhartia, P. K., Boersma, K. F., Veefkind, J. P.,

Gleason, J. F., and Pickering, K. E.: A new stratospheric and tropospheric NO2 retrieval algorithm for nadir-viewing satellite instruments: applications to OMI, Atmos. Meas. Tech., 6, 2607-2626, doi:10.5194/amt-6-2607-2013, 2013.

5

Carpenter, B., Gelman, A., Hoffman, M., Lee, D., Goodrich, B., Betancourt, M., Brubaker, M. A., Guo, J., Li, P. and Riddell, A.: Stan: A probabilistic programming language. Journal of Statistical Software (in press), 2016.

Camredon, M., Aumont, B., Lee-Taylor, J., and Madronich, S.: The SOA/VOC/NOx system: an explicit model of secondary organic aerosol formation, Atmos. Chem. Phys., 7, 5599-5610, doi:10.5194/acp-7-5599-2007, 2007.

Carslaw, K. S, Lee, L. A., Reddington, C. L., Pringle, K. J., Rap, A., Forster, P. M., Mann, G. W., Spracklen, D. V., Woodhouse, M. T., Regayre, L. A., Pierce, J. R.: Large contribution of natural aerosols to uncertainty in indirect forcing. Nature, 503, 67-71, 2013.

15

Charlson et al., 1992 Charlson, R. J., Schwartz, S. E., Hales, J. M., et al.: Climate forcing by anthropogenic aerosols. Science, 255, 423-430, 1992.

de Leeuw, G., Holzer-Popp, T., Bevan, S., Davies, W., Descloitres, J., Grainger, R. G., Griesfeller, J., Heckel, A., Kinne, S., 20 Klüser, L., Kolmonen, P., Litvinov, P., Martynenko, D. North, P. J. R., Ovigneur, B., Pascal, N., Poulsen, C., Ramon, D., Schulz, M., Siddans, R., Sogacheva, L., Tanré, D., Thomas, G. E., Virtanen, T. H., von Hoyningen Huene, W., Vountas, M., Pinnock, S.: Evaluation of seven European aerosol optical depth retrieval algorithms for climate analysis, Remote Sensing of Environment 162, 295-315. DOI information: 10.1016/j.rse.2013.04.023, 2015.

25 Donahue, N. M., Epstein, S. A., Pandis, S. N., and Robinson, A. L.: A two-dimensional volatility basis set: 1. organicaerosol mixing thermodynamics, Atmos. Chem. Phys., 11, 3303-3318, doi:10.5194/acp-11-3303-2011, 2011.

Duncan, B. N., Yoshida, Y., Damon, M. R., Douglass, A. R., and Witte, J. C.: Temperature dependence of factors controlling isoprene emissions, Geophys. Res. Lett., 36, L05813, 2009.

30 Efron, B. and Tibshirani, R.: An Introduction to the Bootstrap. Boca Raton, FL: Chapman \& Hall/CRC. ISBN 0-412-042312, 1993. 
Atmos. Chem. Phys. Discuss., doi:10.5194/acp-2016-625, 2016

Manuscript under review for journal Atmos. Chem. Phys.

Published: 15 July 2016

(C) Author(s) 2016. CC-BY 3.0 License.
Atmospheric

Chemistry

and Physics

Discussions

(c) (7)

Emde, C., Buras-Schnell, R., Kylling, A., Mayer, B., Gasteiger, J., Hamann, U., Kylling, J., Richter, B., Pause, C., Dowling, T., and Bugliaro, L.: The libRadtran software package for radiative transfer calculations (version 2.0.1), Geosci. Model Dev., 9, 1647-1672, doi:10.5194/gmd-9-1647-2016, 2016.

5 Donahue, N. M., Epstein, S. A., Pandis, S. N., and Robinson, A. L.: A two-dimensional volatility basis set: 1. organicaerosol mixing thermodynamics, Atmos. Chem. Phys., 11, 3303-3318, doi:10.5194/acp-11-3303-2011, 2011.

Flexas, J., Escalona, J., Evain, S., Gulias, J., Moya, I., Osmond, C. B., and Medrano, H.: Steady-state chlorophyll fluorescence (Fs) measurements as a tool to follow variations of net $\mathrm{CO} 2$ assimilation and stomatal conductance during water stress in C3 plants, Physiologia Plantarum, 114, 231-240, 2002.

Frost, C. and Thompson, S. G.: Correcting for regression dilution bias: comparison of methods for a single predictor variable. Journal of the Royal Statistical Society: Series A (Statistics in Society), 163: 173-189. doi: 10.1111/1467985X.00164, 2000.

15

Ghent, D.: Land Surface Temperature Validation and Algorithm Verification (Report to European Space Agency), 2012.

Giglio, L., Descloitres, J., Justice, C.O., Kaufman, Y.: An enhanced contextual fire detection algorithm for MODIS. Remote Sensing of Environment, 87:273-282, 2003.

20

Goldstein, A. H. and Galbally, I. E.: Known and Unexplored Organic Constituents in the Earth's Atmosphere, Environmental Science \& Technology, 41, 1514-1521, 2007.

Goldstein, A.H., Koven, C.D., Heald, C.L., and Fung, I.: Biogenic Carbon and Anthropogenic Pollutants Combine to Form a

25 Cooling Haze over the Southeastern US, Proceedings of the National Academy of Sciences, 106, 8835-8840, 2009.

Guenther, A., Karl, T., Harley, P., Wiedinmyer, C., Palmer, P. I., and Geron, C.: Estimates of global terrestrial isoprene emissions using MEGAN (Model of Emissions of Gases and Aerosols from Nature), Atmos. Chem. Phys., 6, 3181-3210, doi:10.5194/acp-6-3181-2006, 2006.

30

Hand, J. L., Schichtel, B. A., Malm, W. C., and Pitchford, M. L.: Particulate sulfate ion concentration and SO2 emission trends in the United States from the early 1990s through 2010, Atmos. Chem. Phys., 12, 10353-10365, doi:10.5194/acp-1210353-2012, 2012. 
Atmos. Chem. Phys. Discuss., doi:10.5194/acp-2016-625, 2016

Manuscript under review for journal Atmos. Chem. Phys.

Published: 15 July 2016

(C) Author(s) 2016. CC-BY 3.0 License.

(c) (i)
Atmospheric

Chemistry

and Physics

Discussions

Hansen, J., Ruedy, R., Glascoe, J., and Sato, M., GISS analysis of surface temperature change. J Geophys Res 104(D24):30997-31022, 1999.

Haywood, J. M., and Shine, K. P.: The effect of anthropogenic sulfate and soot aerosol on the clear sky planetary radiation budget, Geophys. Res. Lett., 22, 603-606, 1995.

Hidy, G. M., Blanchard, C. L., Baumann, K., Edgerton, E., Tanenbaum, S., Shaw, S., Knipping, E., Tombach, I., Jansen, J., and Walters, J.: Chemical climatology of the southeastern United States, 1999-2013, Atmos. Chem. Phys., 14, 11893-11914, doi:10.5194/acp-14-11893-2014, 2014.

10

Holzer-Popp, T., de Leeuw, G., Griesfeller, J., Martynenko, D., Klüser, L., Bevan, S., Davies, W., Ducos, F., Deuzé, J. L., Graigner, R. G., Heckel, A., von Hoyningen-Hüne, W., Kolmonen, P., Litvinov, P., North, P., Poulsen, C. A., Ramon, D., Siddans, R., Sogacheva, L., Tanre, D., Thomas, G. E., Vountas, M., Descloitres, J., Griesfeller, J., Kinne, S., Schulz, M., and Pinnock, S.: Aerosol retrieval experiments in the ESA Aerosol_cci project, Atmos. Meas. Tech., 6, 1919-1957, doi:10.5194/amt-6-1919-2013, 2013.

Horowitz, L. W., Walters, S., Mauzerall, D. L., Emmons, L. K., Rasch, P. J., Granier, C., Tie, X., Lamarque, J.-F., Schultz, M. G., Tyndall, G. S., Orlando, J. J., and Brasseur, G. P.: A global simulation of tropospheric ozone and related tracers: Description and evaluation of MOZART, version 2, J. Geophys. Res., 108, 4784, doi:10.1029/2002JD002853, 2003.

Hudman, R. C., Murray, L. T., Jacob, D. J., Millet, D. B., Turquety, S., Wu, S., Blake, D. R., Goldstein, A. H., Holloway, J., and Sachse, G. W.: Biogenic versus anthropogenic sources of CO in the United States, Geophys. Res. Lett., 35, L04801, doi:10.1029/2007GL032393, 2008.

25 International Panel on Climate Change: Climate Change 2013: The Physical Science Basis. Contribution of Working Group I to the Fifth Assessment Report of the Intergovernmental Panel on Climate Change, edited by: Stocker, T. F., Qin, D., Plattner, G.-K., Tignor, M., Allen, S. K., Boschung, J., Nauels, A., Xia, Y., Bex, V., and Midgley, P. M., Cambridge University Press, Cambridge, United Kingdom and New York, NY, USA, 1535 pp., 2013.

30 Joiner, J., Yoshida, Y., Vasilkov, A. P., Middleton, E. M., Campbell, P. K. E., Yoshida, Y., Kuze, A., and Corp, L. A.: Filling-in of near-infrared solar lines by terrestrial fluorescence and other geophysical effects: simulations and space-based observations from SCIAMACHY and GOSAT, Atmos. Meas. Tech., 5, 809-829, doi:10.5194/amt-5-809-2012, 2012. 
Atmos. Chem. Phys. Discuss., doi:10.5194/acp-2016-625, 2016

Manuscript under review for journal Atmos. Chem. Phys.

Kahn, R. A., Gaitley, B. J., Martonchik, J. V., Diner, D. J., Crean, K. A., and Holben, B.: Multiangle Imaging Spectroradiometer (MISR) global aerosol optical depth validation based on 2 years of coincident Aerosol Robotic Network (AERONET) observations. J. Geophys. Res., 110, D10S04, doi:10.1029/2004JD004706, 2005.

5 Kokkola, H., Korhonen, H., Lehtinen, K. E. J., Makkonen, R., Asmi, A., Järvenoja, S., Anttila, T., Partanen, A.-I., Kulmala, M., Järvinen, H., Laaksonen, A., and Kerminen, V.-M.: SALSA - a Sectional Aerosol module for Large Scale Applications, Atmos. Chem. Phys., 8, 2469-2483, doi:10.5194/acp-8-2469-2008, 2008.

Kokkola, H., Yli-Pirilä, P., Vesterinen, M., Korhonen, H., Keskinen, H., Romakkaniemi, S., Hao, L., Kortelainen, A.,

10 Joutsensaari, J., Worsnop, D. R., Virtanen, A., and Lehtinen, K. E. J.: The role of low volatile organics on secondary organic aerosol formation, Atmos. Chem. Phys., 14, 1689-1700, doi:10.5194/acp-14-1689-2014, 2014.

Kolmonen, P., Sogacheva, L., Virtanen, T. H., de Leeuw, G. and Kulmala, M.: The ADV/ASV AATSR aerosol retrieval algorithm: current status and presentation of a full-mission AOD data set. International Journal of Digital Earth, 1-17, 2015.

15

Krotkov, N. A., McLinden, C. A., Li, C., Lamsal, L. N., Celarier, E. A., Marchenko, S. V., Swartz, W. H., Bucsela, E. J., Joiner, J., Duncan, B. N., Boersma, K. F., Veefkind, J. P., Levelt, P. F., Fioletov, V. E., Dickerson, R. R., He, H., Lu, Z., and Streets, D. G.: Aura OMI observations of regional SO2 and NO2 pollution changes from 2005 to 2015, Atmos. Chem. Phys., 16, 4605-4629, doi:10.5194/acp-16-4605-2016, 2016.

Knyazikhin, Y., Glassy, J., Privette, J. L., Tian, Y., Lotsch, A., Zhang, Y., Wang, Y., Morisette, J. T., Votava, P., Myneni, R.B., Nemani, R. R., Running, S. W.: MODIS Leaf Area Index (LAI) and Fraction of Photosynthetically Active Radiation Absorbed by Vegetation (FPAR) Product (MOD15) Algorithm Theoretical Basis Document, http://eospso.gsfc.nasa.gov/atbd/modistables.html, 1999.

Kühn, T., Merikanto, J., Mielonen, T., Hienola, A., Laakso, A., Bergman, T., Korhonen, H., Laaksonen, A. and Kokkola, H.: ECHAM6-SALSA evaluation part 2: The secondary organic aerosol scheme MOA, in preparation.

Laakso, A., Kokkola, H., Partanen, A.-I., Niemeier, U., Timmreck, C., Lehtinen, K. E. J., Hakkarainen, H., and Korhonen, 30 H.: Radiative and climate impacts of a large volcanic eruption during stratospheric sulfur geoengineering, Atmos. Chem. Phys., 16, 305-323, doi:10.5194/acp-16-305-2016, 2016.

Leaitch, W. R., Macdonald, A. M., Brickell, P. C., Liggio, J., Siostedt, S. L., Vlasenko, A., Bottenheim, J. W., Huang, L., Li, S., Liu, S. K., Toom-Sauntry, D., Hayden, K. A., Sharma, S., Shantz, N. C., Wiebe, H. A., Zhang, W., Abbatt, J., Slowik, J. 
Atmos. Chem. Phys. Discuss., doi:10.5194/acp-2016-625, 2016

Manuscript under review for journal Atmos. Chem. Phys.

Published: 15 July 2016

(c) Author(s) 2016. CC-BY 3.0 License.

(c) (i)

Atmospheric 옹

Chemistry

and Physics

Discussions

G., Chang, R., Russell, L. M., Schwartz, R. E., Takahama, S., Jayne, J. T., and Ng, N.: Temperature response of the submicron organic aerosol from temperate forests, Atmos. Environ., 45, 6696-6704, 2011.

Lihavainen, H., Asmi, E., Aaltonen, V., Makkonen, U. and Kerminen, V.-M.: Direct radiative feedback due to biogenic secondary organic aerosol estimated from boreal forest site observations, Environ. Res. Lett. 10, 104005, 2015.

Liu, Y. Y., Parinussa, R. M., Dorigo, W. A., De Jeu, R. A. M., Wagner, W., van Dijk, A. I. J. M., McCabe, M. F., Evans, J. P.: Developing an improved soil moisture dataset by blending passive and active microwave satellite-based retrievals. Hydrology and Earth System Sciences, 15, 425-436, doi:10.5194/hess-15-425-2011, 2011.

10

Liu, Y. Y., Dorigo, W. A., Parinussa, R. M., de Jeu, R. A. M., Wagner, W., McCabe, M. F., Evans, J. P., van Dijk, A. I. J. M.: Trend-preserving blending of passive and active microwave soil moisture retrievals, Remote Sensing of Environment, 123, 280-297, doi: 10.1016/j.rse.2012.03.014, 2012.

15 Loreto, F., and Schnitzler, J.-P.: Abiotic stresses and induced BVOCs, Trends in Plant Science, 15, 3, 154-166, http://dx.doi.org/10.1016/j.tplants.2009.12.006, 2010.

Paasonen, P., Asmi, A., Petäjä, T., Kajos, M. K., Aijala, M., Junninen, H., Holst, T., Abbatt, J. P. D., Arneth, A., Birmili, W., van der Gon, H. D., Hamed, A., Hoffer, A., Laakso, L., Laaksonen, A., Leaitch, W. R., Plass-Duelmer, C., Pryor, S. C.,

20 Raisanen, P., Swietlicki, E., Wiedensohler, A., Worsnop, D. R., Kerminen, V.-M., and Kulmala, M.: Warming-induced increase in aerosol number concentration likely to moderate climate change, Nature Geoscience., 6, 438-442, 2013.

Penuelas, J. and Staudt, M.: BVOCs and global change, Trends in Plant Sci., 15, 133-144, 2010.

25 Pollastri, S., Tsonev, T., and Loreto, F.: Isoprene improves photochemical efficiency and enhances heat dissipation in plants at physiological temperatures, J. Exp. Bot., 65 (6), 1565-1570, doi:10.1093/jxb/eru033, 2014

Prata, F.: Land Surface Temperature Measurement from Space: AATSR Algorithm Theoretical Basis Document, 2002.

30 Randerson, J. T., van der Werf, G. R., Giglio, L., Collatz, G. J. and Kasibhatla P. S.: Global Fire Emissions Database, Version 2 (GFEDv2.1). Data set. Available on-line [http://daac.ornl.gov/] from Oak Ridge National Laboratory Distributed Active Archive Center, Oak Ridge, Tennessee, U.S.A. doi:10.3334/ORNLDAAC/849, 2007. 
Atmos. Chem. Phys. Discuss., doi:10.5194/acp-2016-625, 2016

Manuscript under review for journal Atmos. Chem. Phys.

Published: 15 July 2016

(C) Author(s) 2016. CC-BY 3.0 License.

(c) (i)
Atmospheric

Chemistry

and Physics

Discussions

Riahi, K., Gruebler, A., and Nakicenovic, N.: Scenarios of long-term socio-economic and environmental development under climate stabilization. Technol Forecast Soc Chang 74(7):887-935, 2007.

Riahi, K., Rao, S., Krey, V., Cho, C., Chirkov, V., Fischer, G., Kindermann, G., Nakicenovic, N., and Rafaj, P.: RCP 8.5 - a 5 scenario of comparatively high greenhouse gas emissions, Climatic Change, 109, 33-57, doi:10.1007/s10584-011-0149-y, 2011.

Russell, A. R., Valin, L. C., and Cohen, R. C.: Trends in OMI NO2 observations over the United States: effects of emission control technology and the economic recession, Atmos. Chem. Phys., 12, 12197-12209, doi:10.5194/acp-12-12197-2012, 102012.

Scott, C. E., Rap, A., Spracklen, D. V., Forster, P. M., Carslaw, K. S., Mann, G. W., Pringle, K. J., Kivekäs, N., Kulmala, M., Lihavainen, H., and Tunved, P.: The direct and indirect radiative effects of biogenic secondary organic aerosol, Atmos. Chem. Phys., 14, 447-470, doi:10.5194/acp-14-447-2014, 2014.

15

Slowik, J. G., Stroud, C., Bottenheim, J. W., Brickell, P. C., Chang, R. Y.-W., Liggio, J., Makar, P. A., Martin, R. V., Moran, M. D., Shantz, N. C., Sjostedt, S. J., van Donkelaar, A., Vlasenko, A., Wiebe, H. A., Xia, A. G., Zhang, J., Leaitch, W. R., and Abbatt, J. P. D.: Characterization of a large biogenic secondary organic aerosol event from eastern Canadian forests, Atmos. Chem. Phys., 10, 2825-2845, doi:10.5194/acp-10-2825-2010, 2010.

20

Spracklen, D. V., Bonn, B., and Carslaw, K. S.: Boreal forests, aerosols and the impacts on clouds and climate, Phil. Trans. R. Soc. A., 366, 4613-4626, 2008.

Stavrakou, T., Müller, J.-F., Bauwens, M., De Smedt, I., Van Roozendael, M., De Mazière, M., Vigouroux, C., Hendrick, F.,

25 George, M., Clerbaux, C., Coheur, P.-F., and Guenther, A.: How consistent are top-down hydrocarbon emissions based on formaldehyde observations from GOME-2 and OMI?, Atmos. Chem. Phys., 15, 11861-11884, doi:10.5194/acp-15-118612015, 2015.

Stevens, B., and Feingold, G.: Untangling aerosol effects on clouds and precipitation in a buffered system. Nature, 461, 30 doi:10.1038/nature08281, 2009.

Stier, P., Feichter, J., Kinne, S., Kloster, S., Vignati, E., Wilson, J., Ganzeveld, L., Tegen, I., Werner, M., Balkanski, Y., Schulz, M., Boucher, O., Minikin, A., Petzold, A.: The aerosol-climate model ECHAM5-HAM. Atmos. Chem. Phys., 5, 1125-1156; doi:10.5194/acp-5-1125-2005, 2005. 
Atmos. Chem. Phys. Discuss., doi:10.5194/acp-2016-625, 2016

Manuscript under review for journal Atmos. Chem. Phys.

Published: 15 July 2016

(c) Author(s) 2016. CC-BY 3.0 License.

\section{(c) (i)}

Atmospheric

Chemistry

and Physics

Discussions

Twomey, S.: Aerosols, clouds, and radiation. Atmos. Environ., 25, 2435-2442, 1991.

Zhang, K., O’Donnell, D., Kazil, J., Stier, P., Kinne, S., Lohmann, U., Ferrachat, S., Croft, B., Quaas, J., Wan, H., Rast, S.,

5 and Feichter, J.: The global aerosol-climate model ECHAM-HAM, version 2: sensitivity to improvements in process representations. Atmos. Chem. Phys, 12, 8911-8949; doi:10.5194/acp-12-8911-2012, 2012.

Veefkind, J. P., Boersma, K. F., Wang, J., Kurosu, T. P., Krotkov, N., Chance, K., and Levelt, P. F.: Global satellite analysis of the relation between aerosols and short-lived trace gases, Atmos. Chem. Phys., 11, 1255-1267, doi:10.5194/acp-11-1255-

$10 \quad 2011,2011$.

Wagner, W., Dorigo, W., de Jeu, R., Fernandez, D., Benveniste, J., Haas, E., and Ertl, M.: Fusion of active and passive microwave observations to create an Essential Climate Variable data record on soil moisture, ISPRS Annals of the Photogrammetry, Remote Sensing and Spatial Information Sciences (ISPRS Annals), Volume I-7, XXII ISPRS Congress,

15 Melbourne, Australia, 25 August-1 September 2012, 315-321, 2012.

20

Table 1: Satellite products used in the project.

\begin{tabular}{|c|c|c|c|}
\hline Product & Usage & $\begin{array}{l}\text { Instrument } \\
\text { depository) }\end{array}$ & Product type \\
\hline $\begin{array}{l}\text { Aerosol optical } \\
\text { depth (AOD) }\end{array}$ & $\begin{array}{l}\text { Amount of aerosols, } \\
2002-2012\end{array}$ & AATSR (Aerosol_cci/ESA) & $\begin{array}{l}\text { Level 3, 1x1 deg, } \\
\text { daily }\end{array}$ \\
\hline $\begin{array}{l}\text { Land surface } \\
\text { temperature (LST) }\end{array}$ & $\begin{array}{l}\text { Temperature, } \\
2002-2012\end{array}$ & $\begin{array}{l}\text { AATSR } \\
\text { (GlobTemperature/ESA) }\end{array}$ & $\begin{array}{l}\text { Level 3, 0.01x0.01 } \\
\text { deg, daily }\end{array}$ \\
\hline $\begin{array}{ll}\text { Nitrogen dioxide } \\
\left(\mathrm{NO}_{2}\right)\end{array}$ & $\begin{array}{l}\text { Proxy for pollution } \\
\text { aerosols, } \\
2005-2012\end{array}$ & (ACDISC/NASA) & $\begin{array}{l}\text { Level } 3,0.25 \times 0.25 \\
\text { deg, daily }\end{array}$ \\
\hline
\end{tabular}


Atmos. Chem. Phys. Discuss., doi:10.5194/acp-2016-625, 2016

Manuscript under review for journal Atmos. Chem. Phys.

Published: 15 July 2016

(c) Author(s) 2016. CC-BY 3.0 License.

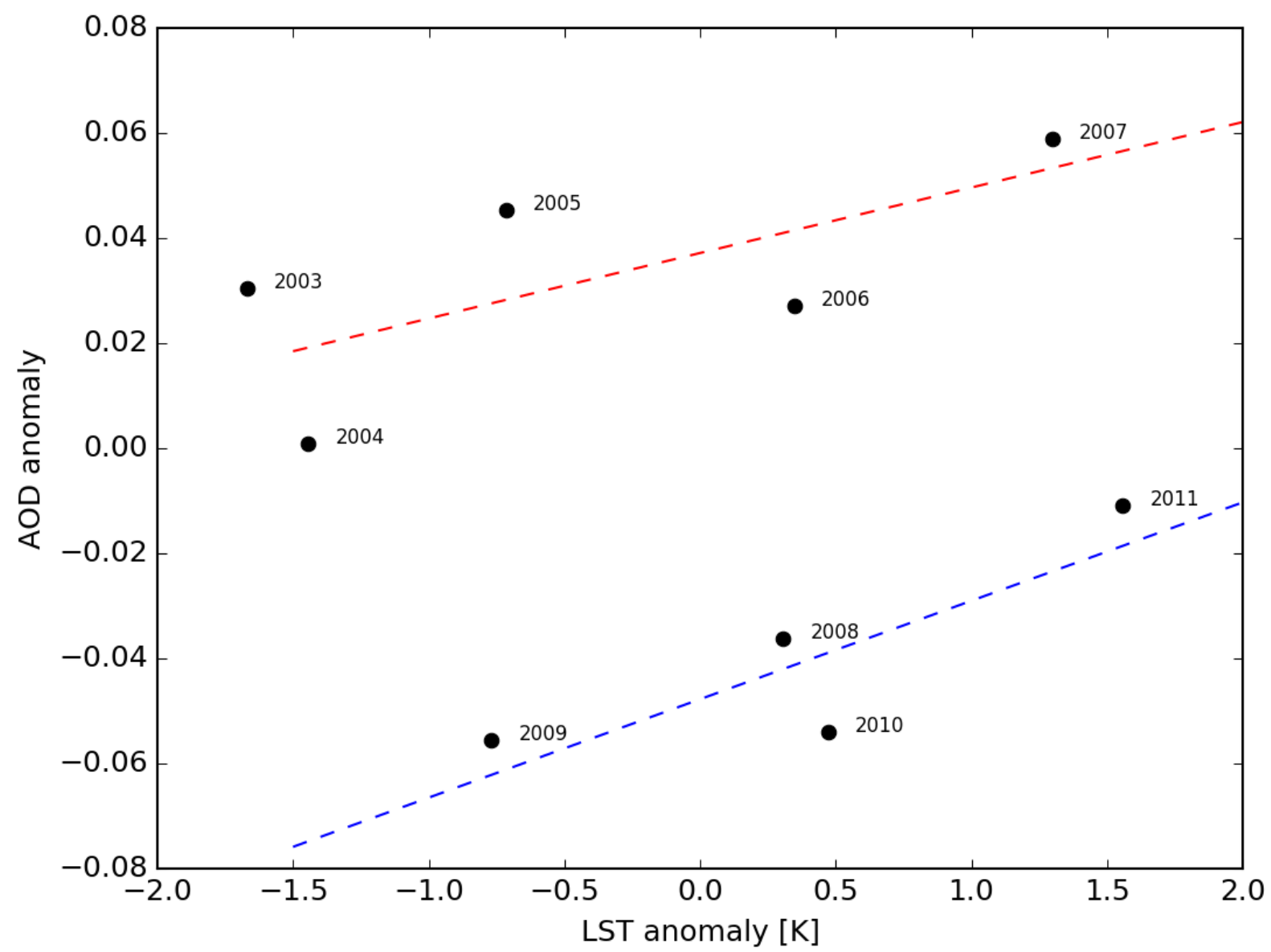

Figure 1: Yearly anomalies in summertime (JJA) aerosol optical depth (AOD) over southeastern US vs. regional mean land surface temperature (LST) for the years 2003-2011. LST and AOD are from L3 AATSR. Linear fits for the two time periods: red $\left(A O D_{a n o}=\right.$ $0.012 L S T_{\text {ano }}+0.037$; years 2003-2007) and blue $\left(A O D_{\text {ano }}=0.019 L S T_{\text {ano }}+0.048\right.$; years 2008-2011). 
Atmos. Chem. Phys. Discuss., doi:10.5194/acp-2016-625, 2016

Manuscript under review for journal Atmos. Chem. Phys.

Published: 15 July 2016

(C) Author(s) 2016. CC-BY 3.0 License.
Atmospheric

Chemistry

and Physics

Discussions
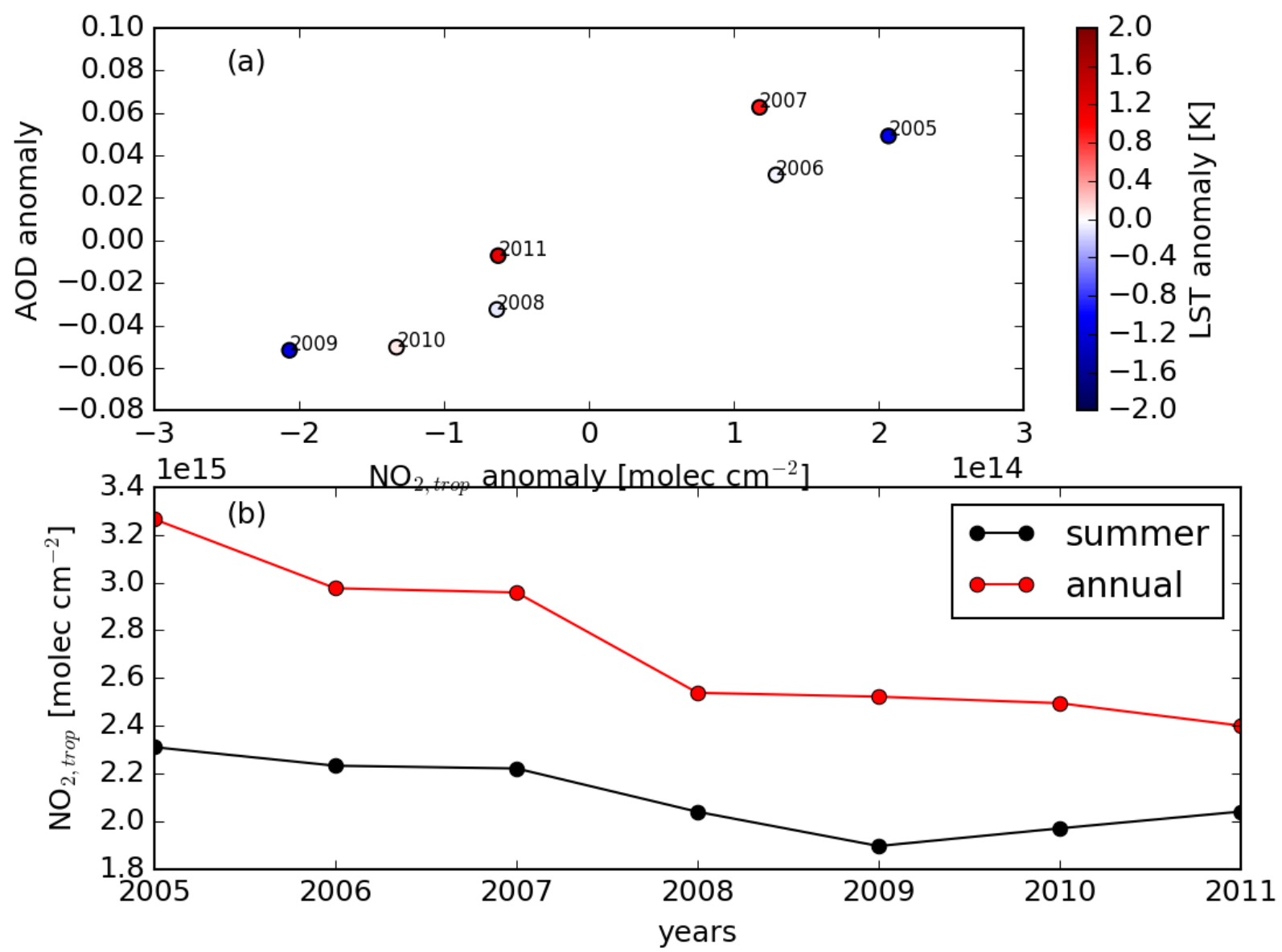

Figure 2: A) Yearly anomalies in summertime (JJA) southeastern US regional mean AOD vs. tropospheric $\mathrm{NO}_{2}$ column densities for the years 2005-2011. Color scale represents LST. B) Annual and summertime averages of tropospheric $\mathrm{NO}_{2}$ over the southeastern US. LST and AOD are from L3 AATSR and tropospheric $\mathrm{NO}_{2}$ from L3 OMI. 
Atmos. Chem. Phys. Discuss., doi:10.5194/acp-2016-625, 2016

Manuscript under review for journal Atmos. Chem. Phys.

Published: 15 July 2016

(c) Author(s) 2016. CC-BY 3.0 License.

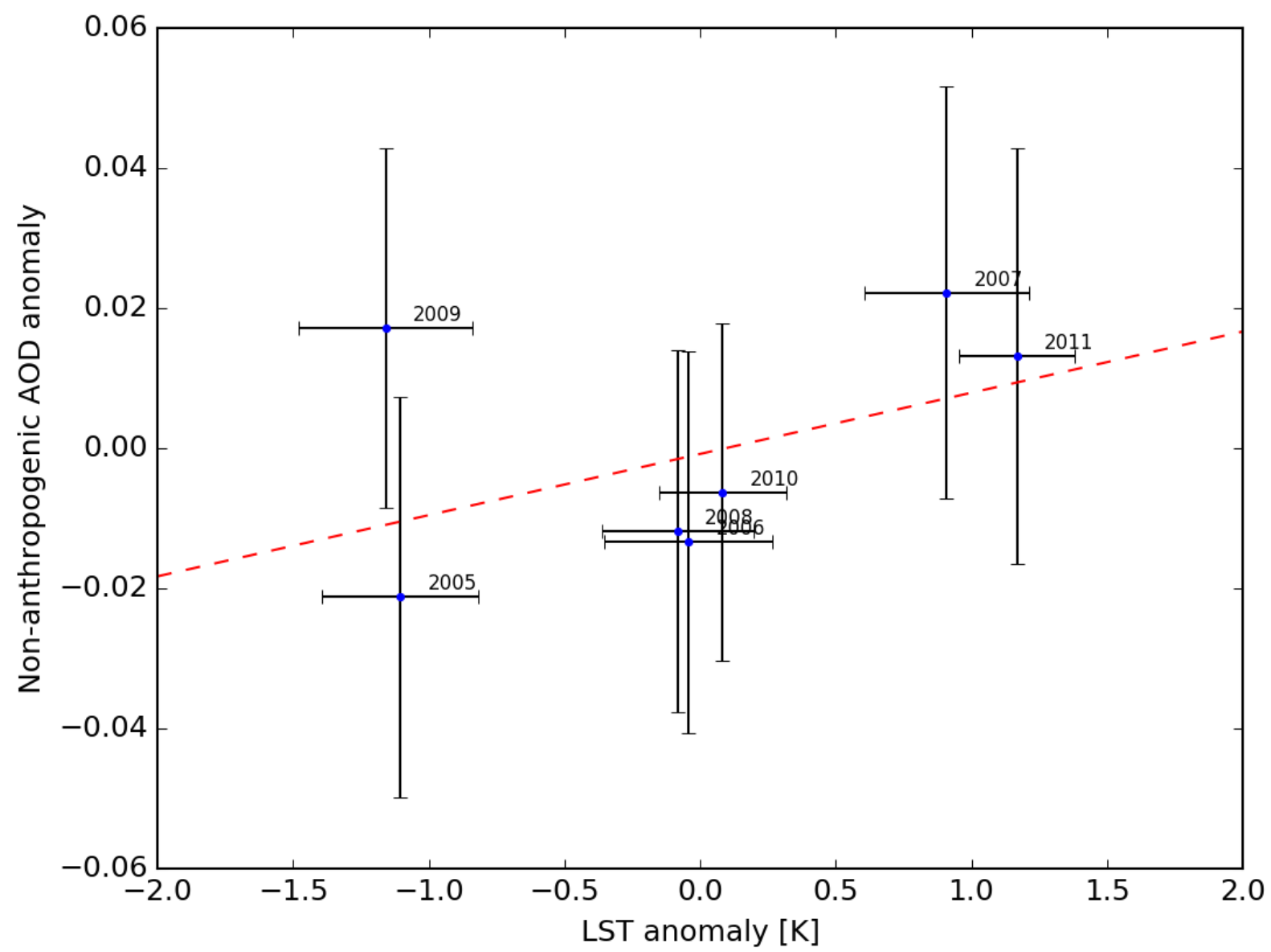

Figure 3: Yearly anomalies in summertime (JJA) southeastern US regional mean "non-anthropogenic" AOD vs. LST, for the years 20052011. Non-anthropogenic AOD is based on L3 AATSR AOD and OMI tropospheric $\mathrm{NO}_{2}$ observations. LST is from L3 AATSR. The dashed line represents the linear fit to the data $\left(A O D_{N A, \text { ano }}=0.009 L S T_{a n o}-0.0008\right)$ and the error bars represent the uncertainty caused by averaging. 
Atmos. Chem. Phys. Discuss., doi:10.5194/acp-2016-625, 2016

Manuscript under review for journal Atmos. Chem. Phys.

Published: 15 July 2016

(C) Author(s) 2016. CC-BY 3.0 License.

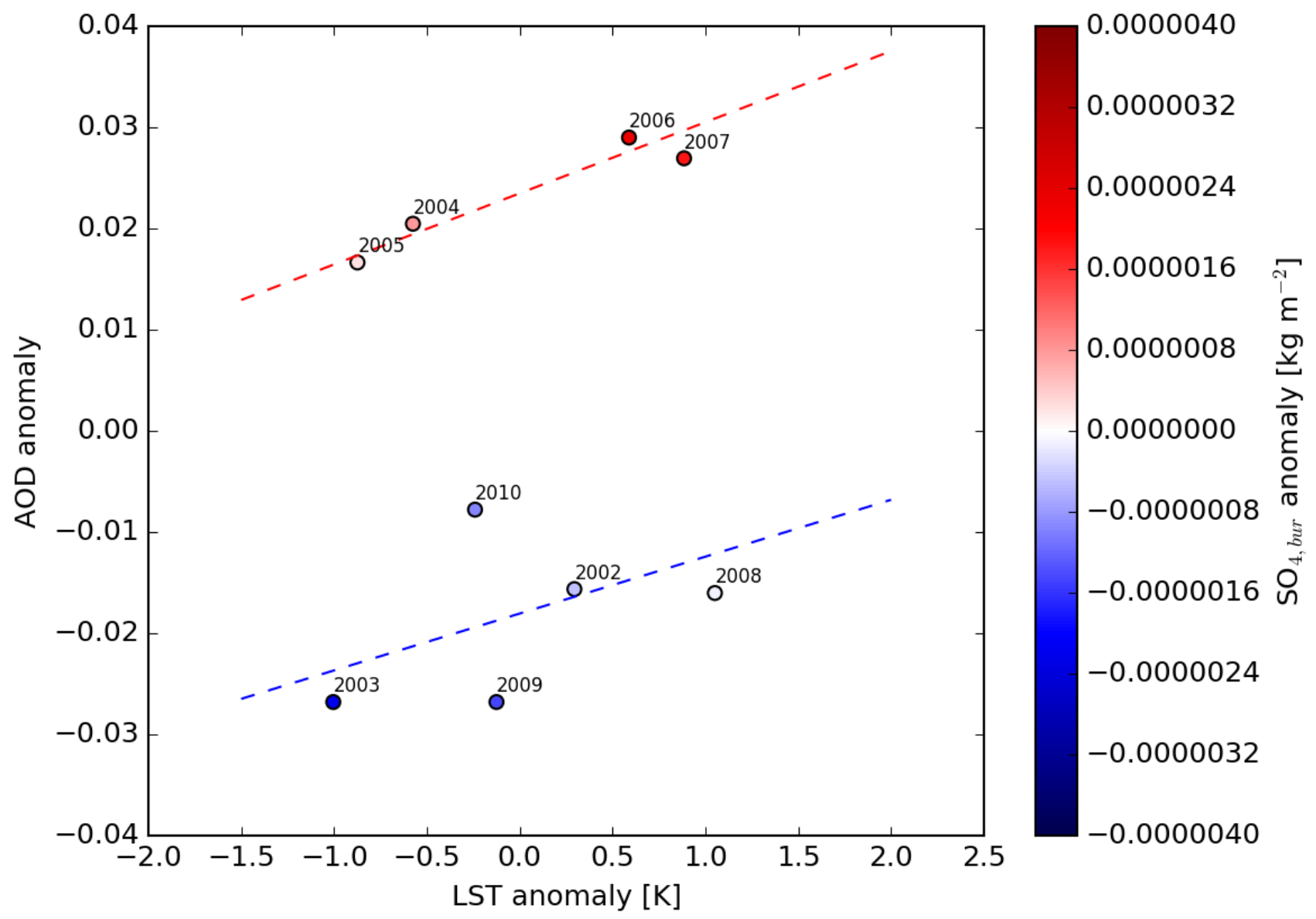

Figure 4: Yearly anomalies in summertime (JJA) southeastern US regional aerosol optical depth (AOD) vs. mean land surface temperature (LST) for the years 2002-2010. Based on the CONTROL simulation. The fitted lines represent two data sets separated based on the $\mathrm{SO}_{4}$ burden: red $\left(A O D_{\text {ano }}=0.007 L S T_{\text {ano }}+0.023\right)$ and blue $\left(A O D_{\text {ano }}=0.006 L S T_{\text {ano }}-0.018\right)$. 
Atmos. Chem. Phys. Discuss., doi:10.5194/acp-2016-625, 2016

Manuscript under review for journal Atmos. Chem. Phys.

Published: 15 July 2016

(c) Author(s) 2016. CC-BY 3.0 License.

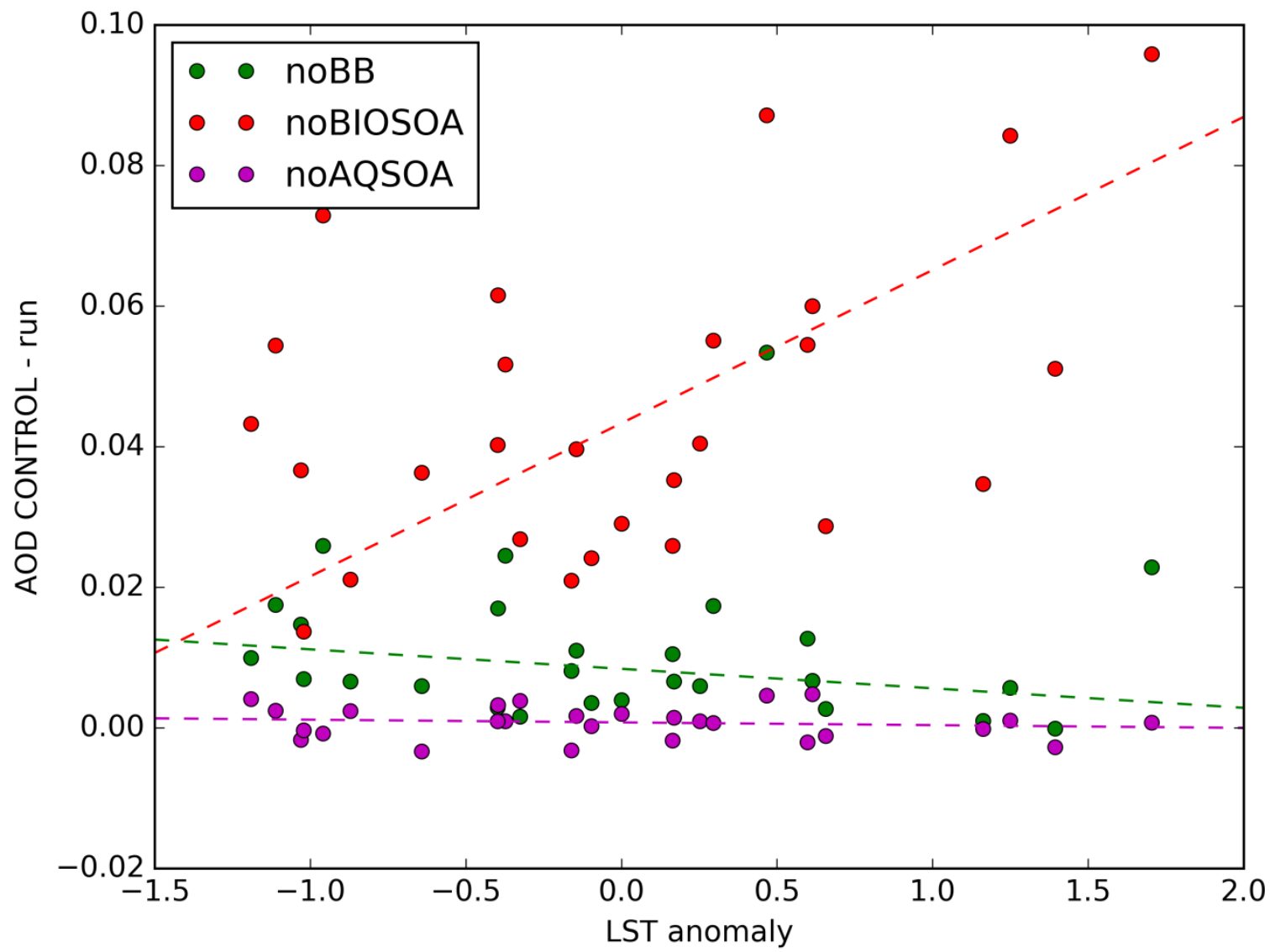

Figure 5: Absolute difference between the monthly AOD values in the CONTROL simulation and the noBB, noSOA and noAQSOA simulations vs. LST anomaly for the summers (JJA) 2002-2010. The linear fits for the differences are: red $\left(A O D_{D i f f}=0.0218 L S T_{a n o}-\right.$ $0.043)$, green $\left(A O D_{\text {Diff }}=-0.0028 L S T_{\text {ano }}+0.008\right)$ and magenta $\left(A O D_{\text {Diff }}=-0.0004 L S T_{\text {ano }}-0.001\right)$. 
Atmos. Chem. Phys. Discuss., doi:10.5194/acp-2016-625, 2016

Manuscript under review for journal Atmos. Chem. Phys.

Published: 15 July 2016

(c) Author(s) 2016. CC-BY 3.0 License.

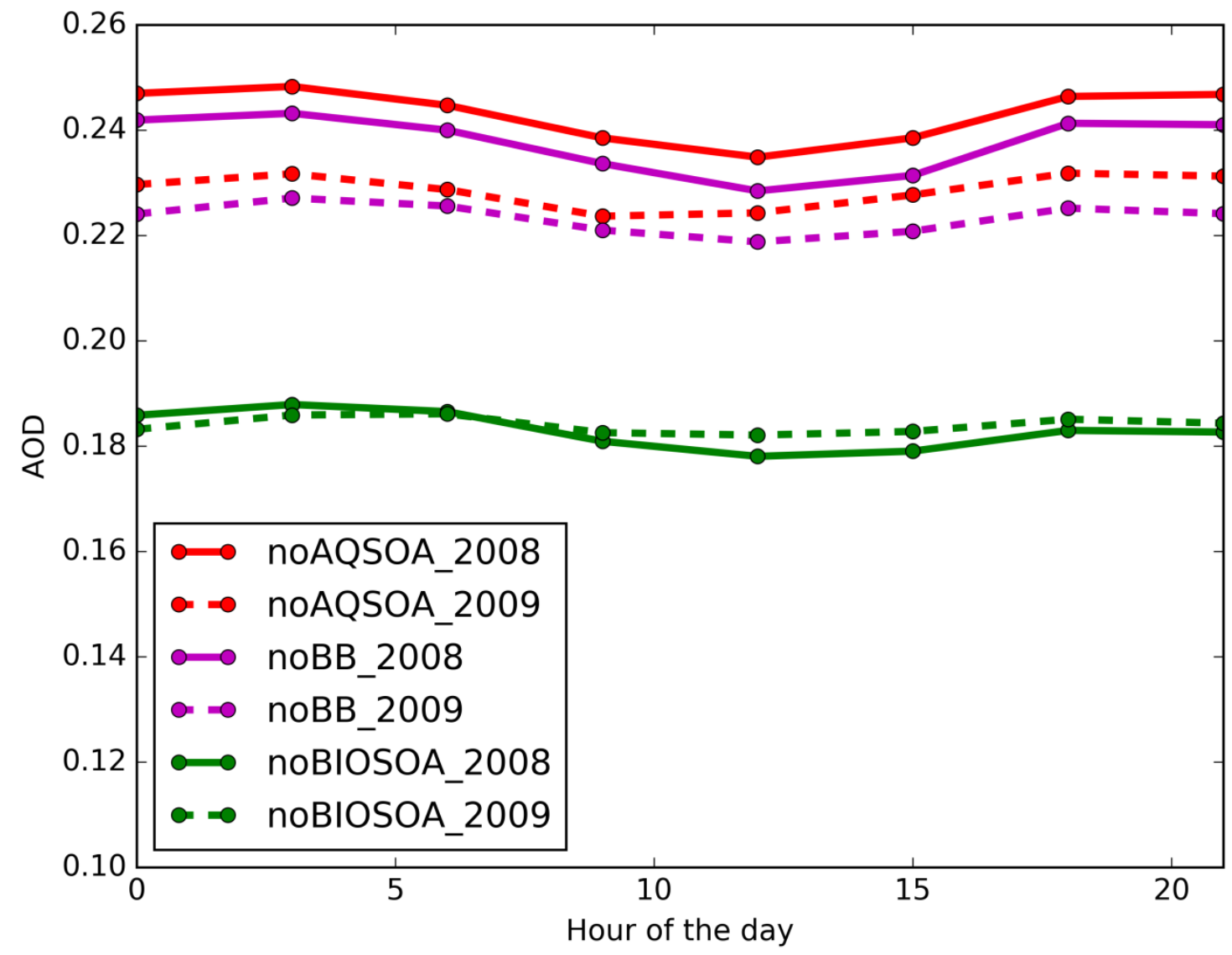

Figure 6: Daily AOD cycle for two summers (JJA) in the southeastern US. Based on 90 day averages from the noAQSOA, noBB and noBIOSOA simulations. Summer 2008 was warmer and summer 2009 colder than the average in the model results. 